\title{
EFEKTIVITAS RUMPON PORTABLE PADA PERIKANAN PANCING ULUR DI BANTEN
}

\section{THE EFFECTIVENESS OF PORTABLE FAD WITH HAND LINE IN BANTEN WATERS}

\author{
Roza Yusfiandayani, Domu Simbolon, Weni Damayanti \\ Departemen Pemanfaatan Sumberdaya Perikanan, \\ Fakultas Perikanan dan Ilmu Kelautan, IPB University \\ Korespondensi: ocha_roza@apps.ipb.ac.id
}

\begin{abstract}
Handlines are a fishing gear that is commonly used by fishermen in Banten Bay. However, the catches obtained by fishermen are few. This is because of the lack of information about the potential fishing ground that fishermen have. One of the methods to increase the effectiveness and efficiency of fishing operation is the information about the availability of fishing ground. The used of portable FADs (Fish Aggregating Devices) technology is expected to create a fishing ground so that fishing operation become more effective and efficient. The research purpose is to compare the productivity and composition of handline catching by using and without portable FAD and to determine the effectiveness of portable FAD. The method used was an experimental fishing method with 20 trips. Research showed that the dominant catches of handline fishing with portable FADs were goatfish, bream, black grouper, mackerel. Goatfish, bream, and black grouper were dominated by large sizes. The total catch of handline was 931 fish. The composition of the catch with the portable FAD was 504 of fish, while without the portable FAD was 427 of fish. The productivity of handline with portable FAD was $1.29 \mathrm{~kg} /$ trip, while the productivity of handline without FAD was $0.99 \mathrm{~kg} /$ trip. Portable FAD use during fishing operations was more effective compare to fishing operations without portable FADs.
\end{abstract}

Keywords: Banten, effectiveness, handline, portable FAD

\begin{abstract}
ABSTRAK
Pancing ulur merupakan alat tangkap yang biasa digunakan nelayan di perairan Teluk Banten. Akan tetapi, hasil tangkapan yang didapatkan nelayan hanya sedikit. Hal ini disebabkan karena nelayan pancing tidak memiliki informasi yang pasti tentang lokasi daerah penangkapan ikan yang potensial. Salah satu cara untuk meningkatkan efektivitas dan efisiensi operasi penangkapan ikan adalah tersedianya informasi daerah penangkapan ikan. Penggunaan teknologi rumpon portable diharapkan dapat menciptakan daerah penangkapan ikan sehingga operasi penangkapan ikan menjadi lebih efektif dan efisien. Penelitian ini bertujuan untuk membandingkan komposisi dan produktivitas hasil tangkapan pancing ulur dengan menggunakan rumpon portable dan tanpa rumpon, serta menentukan efektivitas rumpon portable. Metode penelitian yang digunakan adalah experimental fishing dengan banyak ulangan, yaitu 20 trip. Penelitian menunjukkan bahwa hasil tangkapan dominan pancing ulur yang menggunakan rumpon portable adalah kuniran, kurisi, kerapu hitam, selar. Ikan kuniran, kurisi, dan kerapu hitam didominasi oleh ukuran besar atau layak tangkap. Jumlah total hasil tangkapan pancing ulur sebanyak 931 ekor. Komposisi hasil tangkapan yang menggunakan rumpon portable yaitu 504 ekor dan tanpa menggunakan rumpon portable yaitu 427 ekor. Produktivitas pancing ulur di sekitar rumpon portable sebesar 1,29 kg/trip, sedangkan produktivitas pancing ulur tanpa rumpon 0,99 kg/trip. Penggunaan alat bantu rumpon portable saat operasi penangkapan lebih efektif dibandingkan dengan operasi penangkapan tanpa menggunakan alat bantu rumpon.
\end{abstract}

Kata kunci: Banten, efektivitas, pancing ulur, rumpon portable 


\section{PENDAHULUAN}

\section{Latar belakang}

Provinsi Banten berbatasan langsung dengan tiga wilayah perairan. Sebelah utara berbatasan dengan Laut Jawa, sebelah selatan dengan Samudera Indonesia, sebelah barat dengan Selat Sunda dan sebelah timur dengan dengan DKI Jakarta (Tim Pusat Data Statistik dan Informasi KKP 2017). Wilayah pantai Utara Banten, memiliki beberapa teluk yang dimanfaatkan untuk kegiatan perikanan tangkap, salah satunya adalah Teluk Banten, Kabupaten Serang. Menurut Badan Pusat Statistik Perikanan Kabupaten Serang produksi perikanan tangkap pada tahun 2017 sebesar 7.162,83 ton dan meningkat pada tahun 2014 sebesar 7.553,06 ton.

Produksi perikanan tangkap yang diperoleh merupakan produksi keseluruhan alat tangkap yang ada di Kabupaten Serang, yaitu gillnet, dogol, bagan tancap, bagan perahu, payang, sero, rampus, dan pancing ulur. Pancing ulur merupakan salah satu alat tangkap yang banyak digunakan oleh nelayan. Namun demikian permasalahan yang dihadapi oleh nelayan yang menggunakan pancing ulur, yaitu rendahnya produksi yang didapat. Rendahnya hasil tangkapan yang didapatkan oleh nelayan pancing disebabkan karena nelayan pancing tidak memiliki informasi yang pasti terhadap lokasi daerah penangkapan ikan yang potensial. Daerah penangkapan ikan diperlukan oleh nelayan guna menentukan keberhasilan operasi penangkapan ikan. Menurut Simbolon (2011) nelayan dapat menggunakan rumpon sebagai alat bantu menciptakan daerah penangkapan ikan. Rumpon berfungsi sebagai alat bantu pengumpul ikan yang menggunakan berbagai bentuk dan jenis pengikat/atraktor dari benda padat, berfungsi untuk memikat ikan agar berkumpul, yang dimanfaatkan untuk meningkatkan efisiensi dan efektivitas operasi penangkapan ikan (KKP 2014).

Rumpon berdasarkan pengoperasian digolongkan menjadi rumpon laut dalam dan rumpon laut dangkal. Rumpon tersebut diletakkan secara menetap atau berpindahpindah. Rumpon portable merupakan rumpon yang dapat dipindahkan saat berada di perairan dan digunakan hanya pada saat akan melakukan kegiatan penangkapan ikan (Yusfiandayani et al. 2013). Rumpon portable berbahan fiber dalam menciptakan daerah penangkapan ikan bagi perikanan pancing ulur belum pernah dilakukan dan diujicobakan di Banten.

Tujuan penelitian adalah :

1) Membandingkan komposisi jenis, jumlah, dan ukuran hasil tangkapan pancing ulur dengan menggunakan rumpon portable dan tanpa rumpon;

2) Membandingkan produktivitas hasil tangkapan pancing ulur dengan menggunakan rumpon portable dan tanpa rumpon; dan

3) Menentukan efektivitas rumpon portable dalam menciptakan daerah penangkapan ikan (artificial fishing ground) bagi perikanan pancing ulur.

\section{METODE PENELITIAN}

\section{Waktu dan tempat penelitian}

Penelitian dilakukan selama 20 hari di bulan Maret 2019. Lokasi penelitian dilakukan di Teluk Banten, Kabupaten Serang, Provinsi Banten (Gambar 1).

\section{Peralatan penelitian}

Alat yang digunakan dalam penelitian meliputi kapal, pancing ulur, rumpon portable, tali $\mathrm{PE}$, timbangan, meteran, alat tulis, dan kamera. Rumpon portable berbahan fiber dengan ukuran panjang $62,5 \mathrm{~cm}$, lebar $20 \mathrm{~cm}$, dan tinggi $48 \mathrm{~cm}$ sebagai rangka rumpon. Electric Fish Atractor (EFA) yang terdapat di bagian dalam rumpon portable menggunakan frekuensi suara sebesar 11.000-15.000 Hz.

\section{Metode pengumpulan data}

Metode pengumpulan data yang digunakan dalam penelitian adalah metode experimental fishing yang merupakan uji coba langsung terhadap rumpon portable sebagai alat pengumpul ikan pada alat tangkap pancing ulur. Penggunaan rumpon portable dan tanpa penggunaan rumpon di setiap aktivitas penangkapan berfungsi untuk melihat komposisi dan produktivitas hasil tangkapan dan dilakukan di daerah penangkapan yang sama. Hasil yang diperoleh setelah mengetahui nilai komposisi dan produktivitas, yaitu dapat membandingkan keefektivitasan antara penggunaan rumpon portable dengan tanpa rumpon. 




Gambar 1. Peta lokasi penelitian

Komponen rumpon portable terdiri dari koper, tali PE, EFA (Electric Fish Attractor), dan pemberat. Komponen rumpon portable tersebut diilutrasikan pada Gambar 2.

Koper yang terbuat dari bahan fiber dengan ukuran panjang $62,5 \mathrm{~cm}$, lebar 20 $\mathrm{cm}$, dan tinggi $48 \mathrm{~cm}$. Tali $\mathrm{PE}$ sebagai tali utama yang berfungsi menghubungkan koper dan EFA dengan panjang $9 \mathrm{~m}$. Electric fish atractor menggunakan frekuensi suara sebesar $11.000-15.000 \mathrm{~Hz}$ (Yusfiandayani et al. 2013). Kinerja dari rumpon portable adalah rumpon akan mengeluarkan suara dengan frekuensi sebesar 11.000 - 15.000 $\mathrm{Hz}$ yang terpancarkan dengan luasan area $50 \mathrm{~m}$ - $100 \mathrm{~m}$ (Yusfiandayani et al. 2013). Pemberat yang digunakan dalam penelitian yaitu 3 buah batu yang dijadikan satu.

Konstruksi alat tangkap pancing ulur sangatlah sederhana, sebagaimana ditunjukkan pada Gambar 3. Konstruksi pancing ulur terdiri dari penggulung yang terbuat dari kayu berdiameter 15 $\mathrm{cm}$, tali pancing berbahan polyamide (PA) monofilamen dengan panjang $50 \mathrm{~m}$, kilikili untuk mencegah tali terlilit, pemberat berbahan timah dengan berat $0,5 \mathrm{~kg}$, dan lima mata pancing nomor 17. Jarak tali cabang (branch line) yaitu $50 \mathrm{~cm}$. Umpan yang digunakan berupa umpan buatan. Umpan buatan terbuat dari serat benang sutra berwarna keperak-perakan dan serat kain berwarna kuning, hijau, ataupun oranye.

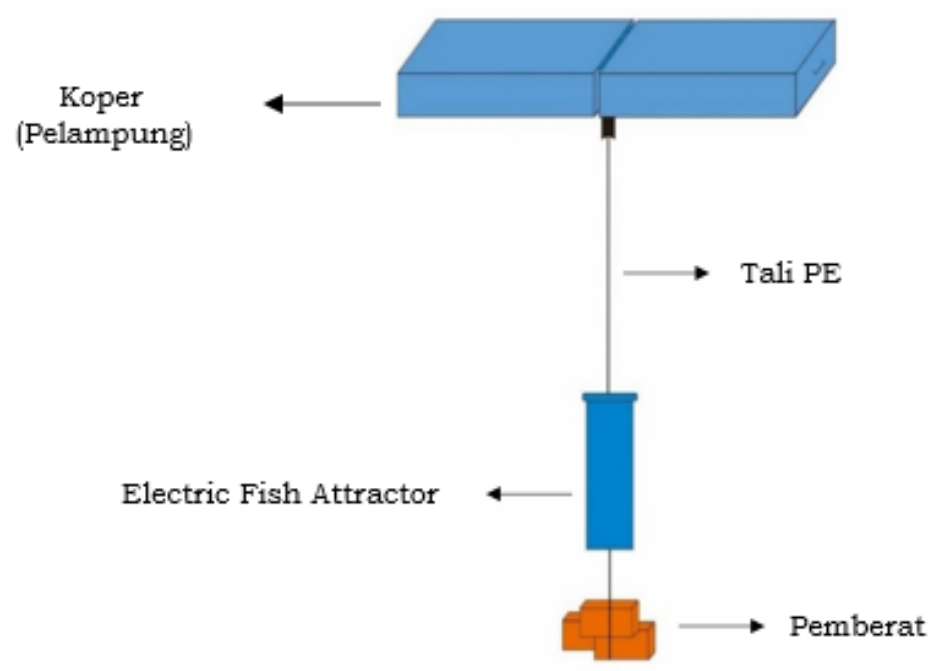

Gambar 2. Rumpon portable 


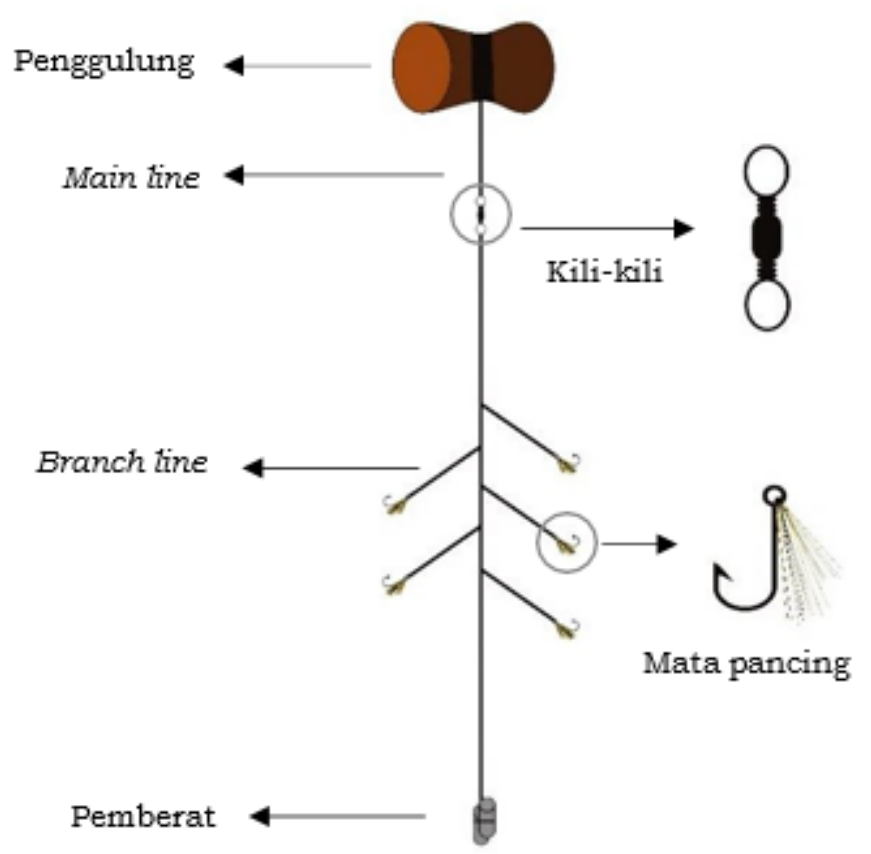

Gambar 3. Alat tangkap pancing ulur

Aktivitas penangkapan ikan dimulai dari fishing base jam 10.00 WIB dan kembali pada jam 14.00 WIB sebanyak 20 trip dengan menggunakan rumpon portable dan 20 trip tanpa menggunakan rumpon. Selanjutnya, pengambilan data jenis, jumlah, dan ukuran panjang ikan dilakukan ketika kapal kembali ke fishing base. Objek yang diamati, yaitu unit penangkapan ikan yang menggunakan alat tangkap pancing ulur yang berada di perairan Teluk Banten. Aspek yang dikaji yaitu komposisi dan produktivitas hasil tangkapan pancing ulur yang menggunakan rumpon portable dan tanpa rumpon. Selain itu, jumlah hasil tangkapan pada masingmasing pengoperasian dapat dibandingkan untuk mendapatkan nilai keefektivitasan rumpon portable. Rincian jenis dan sumber data yang dibutuhkan terangkum pada Tabel 1.

Tabel 1. Jenis dan sumber data yang dibutuhkan

\begin{tabular}{llll}
\hline \multicolumn{1}{c}{ Tujuan penelitian } & $\begin{array}{c}\text { Data yang } \\
\text { dikumpulkan }\end{array}$ & $\begin{array}{c}\text { Metode } \\
\text { pengumpulan data }\end{array}$ & Metode analisis data \\
\hline $\begin{array}{l}\text { Menentukan } \\
\text { komposisi ikan yang } \\
\text { tertangkap dengan } \\
\text { pancing ulur }\end{array}$ & $\begin{array}{l}\text { Jenis, berat, dan } \\
\text { ukuran panjang } \\
\text { ikan }\end{array}$ & Eksperimental & $\begin{array}{l}\text { Analisis komposisi } \\
\text { hasil tangkapan ikan }\end{array}$ \\
$\begin{array}{l}\text { Perbandingan } \\
\text { produktivitas hasil } \\
\text { tangkapan pancing }\end{array}$ & $\begin{array}{l}\text { Bobot ikan } \\
\text { dan waktu } \\
\text { penangkapan }\end{array}$ & Eksperimental & $\begin{array}{l}\text { Analisis produktivitas } \\
\text { ikan hasil tangkapan }\end{array}$ \\
$\begin{array}{l}\text { Efektivitas rumpon } \\
\text { portable pada } \\
\text { perikanan pancing } \\
\text { ulur }\end{array}$ & $\begin{array}{l}\text { Jumlah hasil } \\
\text { tangkapan }\end{array}$ & Eksperimental & $\begin{array}{l}\text { Analisis efektivitas } \\
\text { rumpon portable }\end{array}$ \\
\hline
\end{tabular}




\section{Analisis data}

Komposisi hasil tangkapan

Komposisi hasil tangkapan dihitung berdasarkan jumlah jenis ikan yang tertangkap terhadap jumlah seluruh hasil tangkapan. Proporsi komposisi hasil tangkapan dari rumpon dapat dihitung dengan rumus sebagai berikut (Simbolon et al. 2011):

$$
P=\frac{n i}{N} \times 100 \%
$$

Keterangan:

$P$ : Proporsi satu jenis ikan yang tertangkap pada rumpon

$n i \quad$ : Jumlah jenis ikan ke- $i$

$N$ : Jumlah seluruh hasil tangkapan

\section{Produktivitas hasil tangkapan}

Perhitungan ditentukan berdasarkan perbandingan antara produksi dengan lama waktu operasi penangkapan. Produktivitas menurut Nelwan et al. (2015) dihitung menggunakan rumus:

$$
\text { Produktivitas }=\frac{c}{f}
$$

Keterangan:

$$
\begin{array}{ll}
c & : \text { Hasil tangkapan }(\mathrm{kg}) \\
f & \text { : Upaya penangkapan (jam) } \\
\text { Produktivitas } & \text { : Jumlah hasil tangkapan } \\
& (\mathrm{kg} / \mathrm{jam})
\end{array}
$$

Efektivitas rumpon portable dengan tanpa rumpon

Efektivitas rumpon portable dengan tanpa rumpon yang diujicobakan pada pancing ulur dihitung berdasarkan rasio antara jumlah ikan yang tertangkap terhadap total hasil tangkapan pada suatu rumpon. Tingkat efektivitas rumpon ini dihitung dengan rumus (Simbolon et al. 2011):

$$
E_{i}=\frac{\sum_{j=1}^{n} h i j}{\sum_{j=1}^{n} \sum_{j=1}^{n} h i j} \times 100 \%
$$

Keterangan:

$\mathrm{Ei} \quad$ : Efektivitas rumpon

hij : Hasil tangkapan rumpon portable dan tanpa rumpon $i$ oleh alat tangkap

\section{HASIL DAN PEMBAHASAN}

\section{Komposisi hasil tangkapan pancing ulur}

Jenis dan jumlah hasil tangkapan

Total hasil tangkapan pancing ulur yang diperoleh selama 20 hari penelitian berjumlah 931 ekor, dengan jenis yang cukup beragam (13 spesies). Jumlah hasil tangkapan yang menggunakan rumpon portable sebanyak 504 ekor (54\%) dan yang tanpa menggunakan rumpon sebanyak 427 ekor (46\%). Adapun jumlah ikan hasil tangkapan menurut jenisnya selama dua puluh hari penelitian disajikan pada Gambar 4.

Hasil tangkapan pancing ulur dengan menggunakan rumpon portable didominasi oleh kuniran sebanyak 177 ekor atau sebesar 35,1\%. Kurisi berada di urutan kedua sebanyak 84 ekor dengan persentase sebesar $16,7 \%$. Kerapu hitam sebanyak 70 ekor $(13,9 \%)$, dan selar sebanyak 59 ekor $(11,7 \%)$. Hasil tangkapan pancing ulur tanpa menggunakan rumpon portable didominasi oleh kerapu hitam sebanyak 82 ekor $(19,2 \%)$, kurisi sebanyak 79 ekor $(18,5 \%)$, selar sebanyak 69 ekor $(16,2 \%)$, dan kuniran sebanyak 68 ekor $(15,9 \%)$. Ikan hasil tangkapan dominan yang tertangkap pancing ulur dengan atau tanpa menggunakan rumpon portable adalah sama, yaitu kuniran, kurisi, kerapu hitam, dan selar.

Rumpon portable yang digunakan saat penelitian merupakan jenis rumpon laut dangkal yang berfungsi untuk menangkap ikan pelagis kecil. Namun demikian ikan yang tertangkap adalah ikan demersal dan ikan karang. Hasil tangkapan yang dirasa sedikit biasa disimpan terlebih dahulu ke dalam freezer kulkas dan dijual setelah hasil tangkapan terkumpul. Adapun harga masing-masing ikan pada setiap satu kilogram yang terjual; gerot Rp 35.000, kakap $\mathrm{Rp}$ 55.000, kerapu $\mathrm{Rp}$ 12.000, kleter Rp 5.000, kuwe Rp 45.000, kuniran Rp 30.000, kurisi Rp 20.000, pasir-pasir $\mathrm{Rp}$ 5.000, selar Rp 35000, tambakan Rp 17.000, tembang Rp 5.000, kakap tompel Rp 25.000. Harga jual yang tertera pada Tabel 2 dan Tabel 3 merupakan perhitungan antara berat total ikan dengan harga jual ikan persatuan kilogram. Harga jual ikan hasil tangkapan pancing ulur dengan rumpon portable dan tanpa rumpon dapat dilihat pada Tabel 2 dan Tabel 3. 


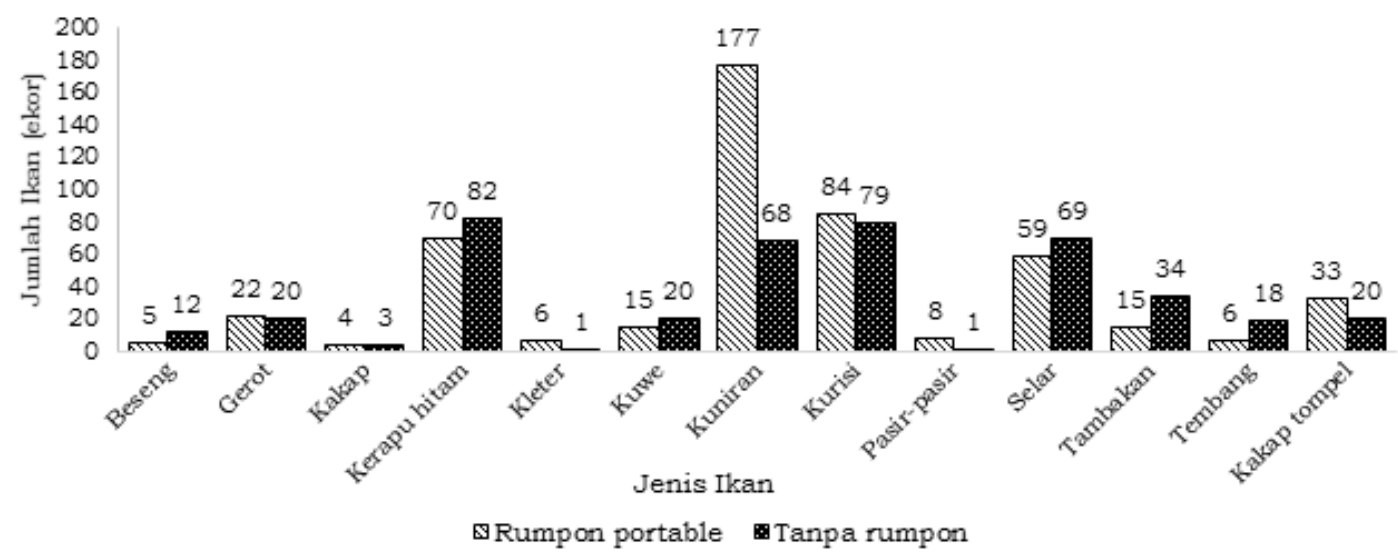

Gambar 4. Jumlah hasil tangkapan per jenis

Berdasarkan Tabel 2 dan Tabel 3 harga jual ikan yang didapat dengan menggunakan alat bantu rumpon portable, pendapatan nelayan selama 20 hari melaut sebesar Rp 661.780, sedangkan tanpa menggunakan alat bantu rumpon, pendapatan nelayan selama 20 hari melaut sebesar Rp 504.710. Hasil tangkapan yang mendapatkan harga jual tertinggi saat pengoperasian pancing dengan rumpon portable adalah kuniran (Rp 170.100), sedangkan harga jual tertinggi saat pengoperasian pancing tanpa rumpon adalah selar (Rp 105.700).

\section{Ukuran panjang ikan}

Ukuran panjang hasil tangkapan ikan yang tertangkap oleh pancing ulur dapat dikategorikan dengan ukuran besar dan ukuran kecil. Kategori ukuran besar dan ukuran kecil didapatkan menurut ukuran layak tangkap pada indikator lenght at first maturity (Lm) dari metadata fishbase. Kategori ikan dengan ukuran besar berada di atas Lm, sedangkan kategori ikan dengan ukuran kecil berada di bawah dan atau sama dengan Lm. Komposisi ukuran ikan hasil tangkapan rumpon portable dan tanpa rumpon menurut jenis ikan dapat dilihat pada Gambar 5.

Gambar 5 menyajikan kategori ukuran besar dan kecil untuk beberapa jenis ikan yang dominan tertangkap, yaitu kuniran, kurisi, kerapu hitam, dan selar. Kuniran kategori ukuran besar jauh lebih banyak tertangkap dengan pancing yang menggunakan rumpon portable dibandingkan dengan tanpa rumpon. Hasil metadata fishbase dari total tangkapan kuniran sebanyak 243 ekor di Teluk Banten memiliki Lm 11,8 cm. Jumlah ikan kuniran kategori ukuran besar dengan kisaran panjang $12 \mathrm{~cm}-18 \mathrm{~cm}$ yang tertangkap pancing dengan rumpon portable sebanyak 142 ekor (59\%) dan 31 ekor (13\%) tertangkap dengan pancing tanpa rumpon. Sedangkan, jumlah ikan kuniran kategori ukuran kecil dengan kisaran panjang 8,5 cm - 11,5 cm sama jumlahnya dengan yang tertangkap pada saat pancing dengan rumpon portable atau tanpa rumpon, yaitu 35 ekor (14\%). Hasil metadata fishbase dari total tangkapan kurisi sebanyak 182 ekor di Teluk Banten memiliki Lm $14 \mathrm{~cm}$. Persentase dari total tangkapan kategori ukuran kecil sebanyak $40 \%$ dengan kisaran panjang $10 \mathrm{~cm}-13,5$ $\mathrm{cm}$, sedangkan persentase kategori ukuran besar sebanyak $60 \%$ dengan kisaran panjang $14 \mathrm{~cm}-22 \mathrm{~cm}$. Hasil metadata fishbase dari total tangkapan kerapu hitam di Teluk Banten memiliki Lm 13,5 cm. Pesentase ikan kerapu hitam dari total tangkapan sebanyak 139 ekor kategori ukuran kecil sebesar 36\% dengan kisaran panjang $9 \mathrm{~cm}-13 \mathrm{~cm}$, sedangkan kategori ukuran besar sebesar 64\% dengan panjang $14 \mathrm{~cm}-21 \mathrm{~cm}$. Hasil metadata fishbase dari total tangkapan selar memiliki Lm 12,9 cm. Persentase ikan selar dari total tangkapan sebanyak 108 ekor kategori ukuran kecil sebanyak 41,7\% dengan kisaran panjang 8 $\mathrm{cm}-12,5 \mathrm{~cm}$, sedangkan kategori ukuran besar 58,3\% dengan ukuran panjang $13 \mathrm{~cm}$ $-20 \mathrm{~cm}$. 
Tabel 2. Hasil tangkapan pancing ulur dengan rumpon portable

\begin{tabular}{clcccr}
\hline No & \multicolumn{1}{c}{ Jenis hasil tangkapan } & $\begin{array}{c}\text { Jumlah } \\
\text { (ekor) }\end{array}$ & $\begin{array}{c}\text { Persentase } \\
(\mathbf{\%})\end{array}$ & $\begin{array}{c}\text { Berat } \\
\text { (kg) }\end{array}$ & $\begin{array}{c}\text { Harga jual } \\
\text { (Rp) }\end{array}$ \\
\hline 1 & Beseng (Apogon ventrifasciatus) & 5 & 1 & 0,09 & 0 \\
2 & Gerot (Pomadasys argyreus) & 22 & 4,4 & 2,10 & 73.500 \\
3 & Kakap (Lutjanus argentimaculatus) & 4 & 0,8 & 1,05 & 57.750 \\
4 & Kerapu hitam (Cephalopholis boenak) & 70 & 13,9 & 3,60 & 43.200 \\
5 & Kleter (Abudefduf vaigiensis) & 6 & 1,2 & 0,50 & 2.500 \\
6 & Kuwe (Carangoides malabaricus) & 15 & 3,0 & 0,86 & 38.700 \\
7 & Kuniran (Upeneus vittatus) & 177 & 35,1 & 5,67 & 170.100 \\
8 & Kurisi (Nemipterus peronit) & 84 & 16,7 & 5,99 & 119.800 \\
9 & Pasir-pasir (Scolopsis vismeri) & 8 & 1,6 & 0,38 & 1.900 \\
10 & Selar (Selaroides leptolepis) & 59 & 11,7 & 2,14 & 74.900 \\
11 & Tambakan (Lutjanus fulvus) & 15 & 3,0 & 0,69 & 11.730 \\
12 & Tembang (Sardinella fimbriata) & 6 & 1,2 & 0,09 & 450 \\
13 & Kakap tompel (Lutjanus johnii) & 33 & 6,5 & 2,69 & 67.250 \\
\hline & & 504 & 100,0 & 25,85 & 661.780 \\
\hline
\end{tabular}

Tabel 3. Hasil tangkapan pancing ulur tanpa rumpon

\begin{tabular}{clcccr}
\hline No & \multicolumn{1}{c}{ Jenis hasil tangkapan } & $\begin{array}{c}\text { Jumlah } \\
\text { (ekor) }\end{array}$ & $\begin{array}{c}\text { Persentase } \\
(\%)\end{array}$ & $\begin{array}{c}\text { Berat } \\
\text { (kg) }\end{array}$ & $\begin{array}{c}\text { Harga jual } \\
\text { (Rp) }\end{array}$ \\
\hline 1 & Beseng (Apogon ventrifasciatus) & 12 & 2,8 & 0,17 & 0 \\
2 & Gerot (Pomadasys argyreus) & 20 & 4,7 & 1,58 & 55.300 \\
3 & Kakap (Lutjanus argentimaculatus) & 3 & 0,7 & 0,51 & 28.050 \\
4 & Kerapu hitam (Cephalopholis boenak) & 82 & 19,2 & 3,64 & 43.680 \\
5 & Kleter (Abudefduf vaigiensis) & 1 & 0,2 & 0,10 & 500 \\
6 & Kuwe (Carangoides malabaricus) & 20 & 4,7 & 1,29 & 58.050 \\
7 & Kuniran (Upeneus vittatus) & 68 & 15,9 & 2,42 & 72.600 \\
8 & Kurisi (Nemipterus peronii) & 79 & 18,5 & 3,61 & 72.250 \\
9 & Pasir-pasir (Scolopsis vismeri) & 1 & 0,2 & 0,03 & 150 \\
10 & Selar (Selaroides leptolepis) & 69 & 16,2 & 3,02 & 105.700 \\
11 & Tambakan (Lutjanus fulvus) & 34 & 8,0 & 1,44 & 24.480 \\
12 & Tembang (Sardinella fimbriata) & 18 & 4,2 & 0,30 & 1.500 \\
13 & Kakap tompel (Lutjanus johnii) & 20 & 4,7 & 1,70 & 42.500 \\
\hline & & 427 & 100,0 & 19,81 & 504.710 \\
\hline
\end{tabular}

\section{Produktivitas hasil tangkapan pancing ulur}

Produktivitas

penangkapan menggunakan pancing ulur dengan alat bantu rumpon portable merupakan jumlah hasil tangkapan yang didapat pada setiap kali pengoperasian. Produktivitas yang dihitung menggunakan trip setiap harinya. Produktivitas hasil tangkapan ikan berdasarkan jenis teknologi (menggunakan rumpon portable dan tanpa rumpon) menunjukan adanya perbedaan dan cenderung berfluktuasi (Gambar 6).

Produktivitas alat tangkap pancing ulur setiap harinya mengalami fluktuasi. Jumlah total trip penangkapan selama penelitian yaitu sebanyak 20 trip dengan lama trip 4 jam setiap harinya. Jumlah total produktivitas hasil tangkapan unit penangkapan pancing ulur yaitu sebesar $2,3 \mathrm{~kg} /$ trip. Produktivitas penangkapan di sekitar rumpon portable yaitu $1,29 \mathrm{~kg} /$ trip, dengan nilai rata-rata $0,06 \mathrm{~kg} /$ trip. 
Sedangkan produktivitas penangkapan tanpa rumpon adalah $0,99 \mathrm{~kg} /$ trip, dengan nilai rata-rata $0,04 \mathrm{~kg} /$ trip. Hal ini sangat dipengaruhi oleh upaya penangkapan nelayan di Perairan Teluk Banten. Nilai produktivitas yang naik dan turun tidak hanya dipengaruhi dari faktor manusia tetapi juga dipengaruhi faktor alam seperti kondisi cuaca, musim, dan arus.

Nilai produktivitas yang didapat setiap harinya tidak lepas dari biaya aktivitas penangkapan ikan yang dikeluarkan oleh nelayan. Biaya aktivitas penangkapan ikan dengan menggunakan pancing ulur disekitar rumpon portable dan tanpa rumpon menunjukkan adanya perbedaan biaya yang dikeluarkan selama aktivitas penangkapan ikan (Tabel 4). Biaya aktivitas penangkapan ikan dalam pengoperasian pancing tanpa rumpon lebih besar dibandingkan dengan pancing yang menggunakan rumpon portable.

\section{Efektivitas rumpon portable}

Pengertian efektivitas pada rumpon portable adalah suatu kemampuan untuk mendapatkan hasil tangkapan yang optimum sesuai dengan tujuan penangkapan. Efektivitas rumpon portable terhadap operasi penangkapan ikan menggunakan alat tangkap pancing ulur di Perairan Teluk Banten dapat dilihat pada Tabel 5.

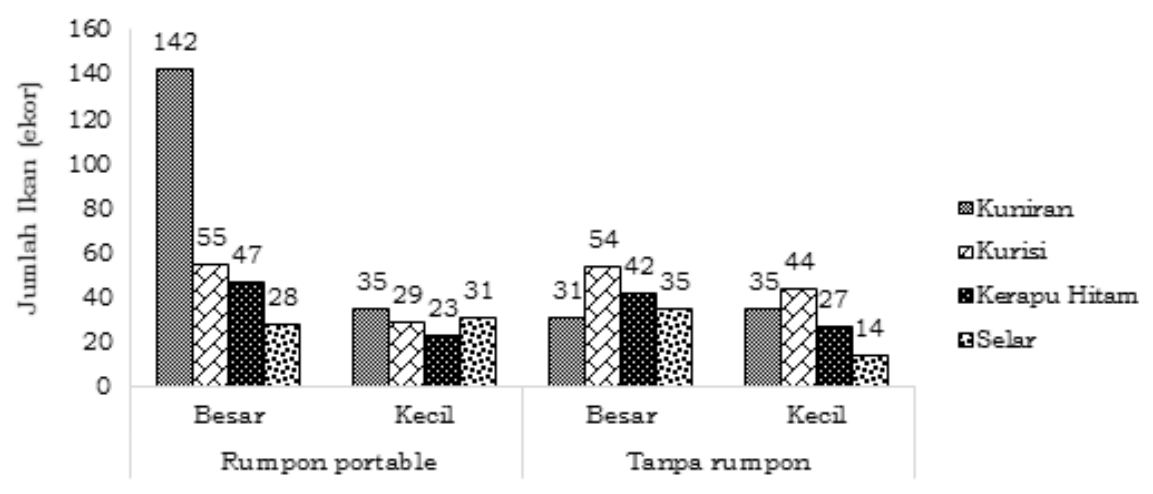

Kategori ukuran ikan pada setiap perlakuan

Gambar 5. Komposisi ukuran ikan menurut jenis ikan dan perlakuan

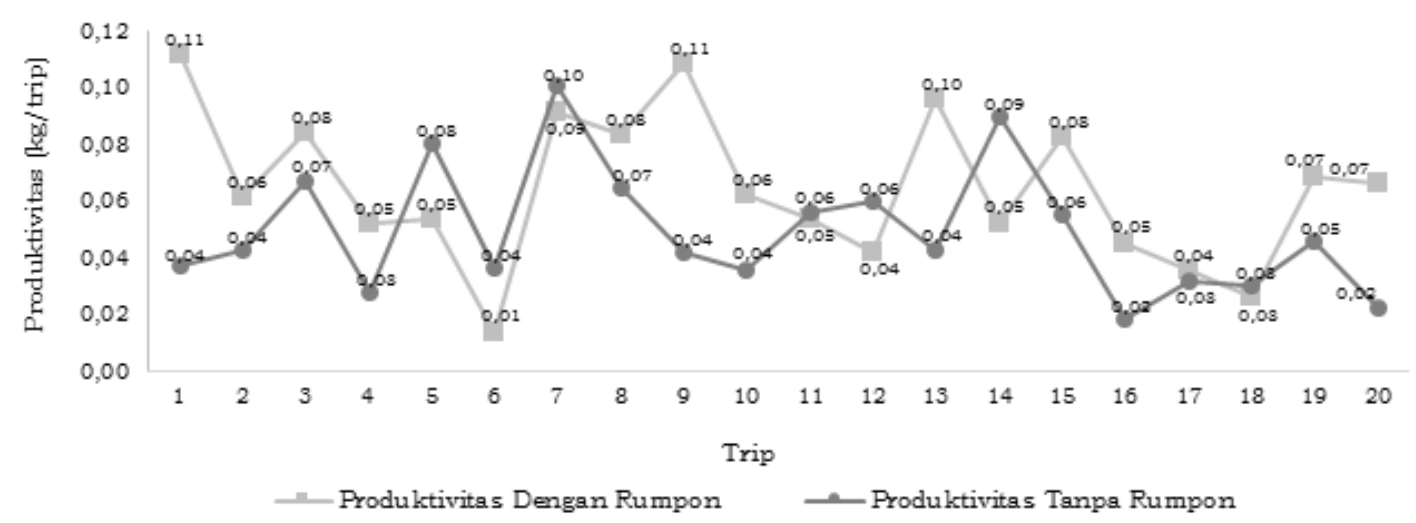

Gambar 6. Produktivitas pancing ulur dengan dan tanpa rumpon portable

Tabel 4. Biaya aktivitas penangkapan ikan

\begin{tabular}{lcc}
\hline & Rumpon portable & Tanpa rumpon \\
\hline Jumlah trip penangkapan & 20 Trip & 20 Trip \\
Harga bahan bakar per liter & Rp 10.000 & $\mathrm{Rp} 10.000$ \\
Konsumsi makanan & $\mathrm{Rp} 20.000$ & $\mathrm{Rp} 20.000$ \\
Rata-rata jarak jelajah per trip & $6 \mathrm{~km}$ & $12 \mathrm{~km}$ \\
\hline \multicolumn{1}{c}{ Total biaya } & $\mathrm{Rp} 500.000$ & $\mathrm{Rp} 1.000 .000$ \\
\hline
\end{tabular}


Tabel 5. Efektivitas rumpon portable berdasarkan jumlah tangkapan

\begin{tabular}{ccc}
\hline Perlakuan & Total tangkapan (ekor) & Efektivitas rumpon (\%) \\
\hline Rumpon portable & 504 & 54 \\
Tanpa rumpon & 427 & 46 \\
\hline Total & 931 & 100 \\
\hline
\end{tabular}

Jumlah total ikan hasil tangkapan pancing selama 20 hari penelitian sebanyak 931 ekor yang terdiri atas 13 jenis ikan yang berbeda. Jumlah hasil tangkapan pancing dengan menggunakan rumpon portable sebanyak 504 ekor dan jumlah hasil tangkapan pancing tanpa menggunakan rumpon sebanyak 427 ekor. Hasil tangkapan yang didapat dihitung untuk mencari nilai efektivitas pada penggunaan rumpon portable. Efektivitas penggunaan alat bantu penangkapan berupa rumpon portable memiliki tingkat efektivitas yang lebih tinggi, yaitu $54 \%$ sedangkan penangkapan tanpa menggunakan rumpon lebih rendah, yaitu 46\%. Menurut Baskoro et al. (2006) nilai efektivitas alat tangkap bagan (lift net) dapat dikategorikan menjadi tiga, yaitu: apabila nilainya kurang dari 50\% dapat diklasifikasikan bahwa suatu alat tangkap memiliki efektivitas rendah, nilai $50 \%-80 \%$ alat tangkap tersebut memiliki nilai efektivitas cukup baik, dan nilai $80 \%-100 \%$ suatu alat tangkap memiliki efektivitas tinggi. Bila dibandingkan dengan nilai-nilai efektivitas alat tangkap bagan, pancing yang menggunakan rumpon portable memiliki efektivitas cukup baik, sedangkan pancing tanpa menggunakan rumpon memiliki efektivitas yang kurang. Berdasarkan nilai efektivitas tersebut maka rumpon portable dapat digunakan sebagai alternatif alat bantu penangkapan untuk alat tangkap pancing ulur, walaupun masih perlu perbaikan untuk mendapatkan hasil yang optimal.

\section{KESIMPULAN DAN SARAN}

\section{Kesimpulan}

1. Jumlah total hasil tangkapan pancing ulur sebanyak 931 ekor dan berat 45,66 kg. Komposisi hasil tangkapan mencakup 504 ekor (54\%) di sekitar rumpon portable dan 427 ekor (46\%) hasil tangkapan tanpa rumpon.

2. Produktivitas pancing ulur di sekitar rumpon portable sebesar $1,29 \mathrm{~kg} /$ trip, dengan nilai rata-rata $0,06 \mathrm{~kg} /$ trip, sedangkan produktivitas pancing ulur tanpa rumpon $0,99 \mathrm{~kg} /$ trip, dengan nilai rata-rata $0,04 \mathrm{~kg} /$ trip.

3. Penggunaan alat bantu rumpon portable saat operasi penangkapan lebih efektif dibandingkan dengan operasi penangkapan tidak menggunakan alat bantu rumpon. Nilai efektivitas pada rumpon portable sebesar 54\% (kategori cukup baik) dan nilai efektivitas tanpa rumpon sebesar 46\% (kategori rendah).

\section{Saran}

1. Perlu dilakukannya penelitian lanjutan mengenai respon ikan terhadap frekuensi suara.

2. Perbaikan pada konstruksi rumpon portable dengan memperbaiki kerangka tempat meletakkan EFA menjadi kedap air sehingga konstruksi yang digunakan dapat lebih kokoh dan tidak mengalami kebocoran.

\section{DAFTAR PUSTAKA}

Badan Pusat Statistik Perikanan Kabupaten Serang. 2017. Produksi dan Nilai Penangkapan Ikan di Laut Menurut Jenis Ikan di Kabupaten Serang.

Baskoro MS, Telussa RF, Purwangka F. 2006. Efektivitas Bagan Motor di Perairan Waai, Pulau Ambon. Prosiding Seminar Perikanan Tangkap. Bogor (ID): 115-121.

[KKP] Kementerian Kelautan dan Perikanan. 2014. Peraturan Menteri Kelautan dan Perikanan Republik Indonesia. Nomor 26/PERMEN-KP/2014 tentang Rumpon.

Nelwan AFP, Sudirman, Nursam M, Yunus M. 2015. Produktivitas Penangkapan Ikan Pelagis di Perairan Kabupaten Sinjai pada Musim Peralihan BaratTimur. Jurnal Perikanan. 17(1): 1826.

Simbolon D, Jeujanan B, Wiyono E. 2011. Efektivitas Pemanfaatan Rumpon 
pada Operasi Penangkapan Ikan di Perairan Kei Kecil, Maluku Tenggara. Journal Marine Fisheries. 2(1): 19-28.

Yusfiandayani R, Jaya I, Baskoro MS. 2013. Pengkajian terhadap Rumpon Portable untuk Pengelolaan Ikan Tuna dan Cakalang Secara Berkelanjutan. [Laporan Akhir Penelitian Lintas Fakultas]. Bogor (ID): Lembaga Penelitian dan Pengabdian kepada Masyarakat. Institut Pertanian Bogor.

Yusfiandayani R, Jaya I, Baskoro MS. 2013. Uji Coba Penangkapan pada Rumpon Portable di Perairan Palabuhanratu. Jurnal Teknologi Perikanan dan Kelautan. 4(1): 89-98. 